\title{
Phosphorus translocation by red deer on a subalpine grassland in the Central European Alps
}

\section{Journal Article}

Author(s):

Schütz, Martin; Risch, Anita C.; Achermann, Gérald; Thiel-Egenter, Conny; Page-Dumroese, Deborah S.; Jurgensen, Martin F.; Edwards, Peter J.

\section{Publication date:}

2006-06

\section{Permanent link:}

https://doi.org/10.3929/ethz-b-000022898

Rights / license:

In Copyright - Non-Commercial Use Permitted

Originally published in:

Ecosystems 9(4), https://doi.org/10.1007/s10021-006-0091-4 


\title{
Phosphorus Translocation by Red Deer on a Subalpine Grassland in the Central European Alps
}

\author{
Martin Schütz, ${ }^{1 *}$ Anita C. Risch, ${ }^{1,2}$ Gérald Achermann, ${ }^{1}$ \\ Conny Thiel-Egenter, ${ }^{1,3}$ Deborah S. Page-Dumroese, ${ }^{4}$ Martin F. Jurgensen, ${ }^{5}$ \\ and Peter J. Edwards ${ }^{6}$
}

\begin{abstract}
${ }^{1}$ Swiss Federal Institute for Forest, Snow and Landscape Research, CH-8903 Birmensdorf, Switzerland; ${ }^{2}$ Department of Biology, Biological Research Laboratories, Syracuse University, Syracuse, New York 13244, USA; ${ }^{3}$ Institute of Systematic Botany, University of Zurich, CH-8008, Zurich, Switzerland; ${ }^{4}$ Rocky Mountain Research Station, USDA Forest Service, Moscow, Idaho 83843, USA; ${ }^{5}$ School of Forest Resources and Environmental Science, Michigan Technological University, Houghton, Michigan 49931, USA; ${ }^{6}$ Geobotanical Institute, Swiss Federal Institute of Technology, CH-8044 Zurich, Switzerland
\end{abstract}

\begin{abstract}
We examined the role of red deer (Cervus elaphus L.) in translocating phosphorus (P) from their preferred grazing sites (short-grass vegetation on subalpine grasslands) to their wider home range in a subalpine grassland ecosystem in the Central European Alps. Phosphorus was used because it is the limiting nutrient in these grasslands. When we compared $\mathrm{P}$ removal of aboveground biomass due to grazing with $\mathrm{P}$ input due to the deposit of feces on a grid of 268 cells $(20 \mathrm{~m} \times 20 \mathrm{~m})$ covering the entire grassland, we detected distinct spatial patterns: the proportion of heavily grazed short-grass vegetation increased with increasing soil-P pool, suggesting that red deer preferably grazed on grid cells with a higher soil-P pool. Biomass consumption related to increased proportion of shortgrass vegetation, and therefore $\mathrm{P}$ removal, increased with increasing soil-P pool. However, within the two vegetation types (short-grass and tall-grass), consumption was independent from soil-P pool. In addition, $\mathrm{P}$ input rates from defecation increased with increasing soil-P pool, resulting in a constant mean net $\mathrm{P}$ loss of $0.083 \mathrm{~kg}$
\end{abstract}

Received 15 July 2004; accepted 8 August 2005; published online 31 May 2006.

*Corresponding author; e-mail: martin.schuetz@wsl.ch $\mathrm{ha}^{-1} \mathrm{y}^{-1}(0.03 \%-0.07 \%$ of soil-P pool) independent of both soil-P pool and vegetation type. Thus, there was no $\mathrm{P}$ translocation between grid cells with different soil-P pools or between short-grass and tall-grass vegetation. Based on these results, it is likely that the net rate of P loss is too small to explain the observed changes in vegetation composition from tall-herb/meadow communities to short-grass and from tall-grass to short-grass on the grassland since 1917. Instead, we suggest that the grazing patterns of red deer directly induced succession from tall-herb/meadow communities to short-grass vegetation. Yet, it is also possible that long-term net soil-P losses indirectly drive plant succession from short-grass to tall-grass vegetation, because nutrient depletion could reduce grazing pressure in short-grass vegetation and enable the characteristic tall-grass species Carex sempervirens Vill. to establish.

Key words: Cervus elaphus; elimination pattern; grazing pattern; phosphorus removal/input; succession; Swiss National Park.

\section{INTRODUCTION}

There are many potential effects of large herbivores on vegetation. Apart from increasing or decreasing primary production and changing species compo- 
sition, species richness, and the physical structure of the vegetation itself (Collins and others 1998; Gough and Grace 1998; Knapp and others 1999; Virtanen and others 2002), large mammalian grazers may also accelerate nutrient turnover (Detling 1988; McNaughton and others 1997; Frank and Evans 1997; Knapp and others 1999). Spatial patterns of nutrients can be altered by grazers such as sheep, horses, and rabbits, which feed over a wide area, but defecate in a small area (Edwards and Hollis 1982; Willot and others 2000). Such feeding behavior results in a gradual impoverishment of the wider grazing range but a continued enrichment of small areas within it. Bokdam (2001) found that the excreta of cattle was deposited at resting places that covered only $2.5 \%$ of their grazing range in a Dutch heathland, and that $75 \%$ of the heathland was still excreta-free after 10 years of grazing. In the European Alps, the traditional system of dairy farming may also promote such patterns. Nutrients accumulate around huts and stables, where cattle rest and are milked (Spatz 1980). In contrast, other large herbivores feed in small and nutrient-rich areas, but defecate in much larger areas (Putman 1986). Various studies have shown that female red deer prefer nutrient-rich grasslands for grazing (Charles and others 1977; Clutton-Brock and others 1987; Gordon 1989), and that nutrients are transferred from these small grazing sites into the wider home range (Schoenecker and others 2002).

We believe that such a change in nutrient transfer took place on subalpine grasslands in the Swiss National Park (SNP). Agricultural management ceased with the foundation of the park in 1914, when domestic livestock (cattle and sheep), which had grazed on the subalpine grasslands for several centuries, were removed from the park area. Braun-Blanquet and others (1931) reported that tall-herb/meadow communities dominated the vegetation around the abandoned stables and on former cattle resting places where high input of cattle excreta had enriched the soil nutrient concentrations. Where cattle predominantly grazed but did not rest, tall-grass pastures dominated by the evergreen sedge Carex sempervirens Vill. developed. Soon after the park's establishment, locally extinct red deer remigrated into the area (Haller 2002), and the nutrient-enriched tall-herb/meadow communities of abandoned subalpine grasslands became preferred nocturnal grazing sites for hinds (Stüssi 1970).

The vegetation development since the foundation of the park is well documented by time-series data on vegetation structure and composition. These data were collected every 5-10 years on more than 150 permanent plots established on these subalpine grasslands as early as 1917 (Achermann and others 2000; Grämiger and Krüsi 2000; Wildi and Schütz 2000). Between the park's establishment and 1960 , tall-herb/meadow communities were completely replaced by short-grass pastures. This process was accompanied by significant changes in vegetation composition (Achermann and others 2000): tallgrowing herb and grass species (for example, Aconitum compactum Rchb., Chenopodium bonus-henricus L., Deschampsia caespitosa (L.) P.B., Trisetum flavescens (L.) P.B.) were replaced by small-growing grasses such as Festuca rubra L. and Briza media L. Later in the century (1970/1980), short-grass areas in proximity to tall-grass pastures (former cattle-grazing areas) were invaded by Carex sempervirens. Both the changes from tall-herb/meadow communities to short-grass pastures and the development of short-grass to tall-grass pastures may have been driven by red deer nutrient translocations.

Focusing on phosphorus (P), we hypothesized that on subalpine grasslands in the SNP: (a) red deer hinds prefer to graze on P-rich sites, (b) preferential grazing will deplete these sites, and (c) P is translocated from preferred nighttime grazing sites (short-grass vegetation on subalpine grasslands) to rarely grazed tall-grass vegetation or to daytime ranges in the surrounding forests or alpine grasslands.

\section{Study Site}

The study was conducted in a subalpine grassland ecosystem (Alp Stabelchod) within the SNP. The park was founded in 1914 and is located in the southeastern part of Switzerland $\left(46^{\circ} 40^{\prime} \mathrm{N}\right.$, $10^{\circ} 15^{\prime} \mathrm{E}$ ). It occupies an area of approximately 170 $\mathrm{km}^{2}$ with $85 \mathrm{~km}^{2}$ covered by vegetation (subalpine/ alpine grasslands and forests). The elevation ranges between 1,400 and 3,174 $\mathrm{m}$.

Alp Stabelchod (10.7 ha) is located at an elevation of $1,950 \mathrm{~m}$ and has an uniform slope of $6^{\circ}$ in a southerly direction. The parent material consists of mainly dolomite sediments. The average annual temperature is $0.2^{\circ} \mathrm{C} \pm 0.76$ (mean $\pm \mathrm{SD}$ ) and the mean precipitation is $925 \mathrm{~mm} \pm 162$ (recorded at the park's weather station: Buffalora 1,977 m). The growing season is from early June to the end of September. The two vegetation types found on Alp Stabelchod today are easily recognizable. As a result of intensive grazing, the vegetation height of the short-grass type is approximately $2 \mathrm{~cm}$; by contrast, the tall-grass type, which is dominated by Carex sempervirens tussocks, exceeds $20 \mathrm{~cm}$ in 
height. Mountain pine (Pinus montana Miller) is the predominant stand-forming species in the surrounding forests (Risch and others 2003).

\section{Materials AND Methods}

Plant and mineral soil sampling was conducted on a systematic grid of 268 cells $(20 \mathrm{~m} \times 20 \mathrm{~m})$, which encompassed the entire grassland area of Alp Stabelchod (10.7 ha). We focused on P cycling, because $\mathrm{P}$ offers the following advantages over other nutrients: (a) $\mathrm{P}$ is the limiting nutrient in subalpine and alpine grassland ecosystems (Dietl 1994); (b) $\mathrm{P}$ is mainly excreted with dung and not with urine (Wu and others 2000), which makes it much easier to quantify nutrient return in excreta (compared for example, to nitrogen); and (c) soil-P is immobile and therefore leaching losses are low (Hilal and others 1973).

\section{Vegetation}

The proportion $(\%)$ of both short-grass and tallgrass vegetation was visually estimated in each grid cell $(20 \mathrm{~m} \times 20 \mathrm{~m})$ in the summer of 1998 . Shortgrass was defined as vegetation that was grazed to approximately $2 \mathrm{~cm}$ vegetation height. Vegetation composition was sampled in July and August 1998 on a subplot $(1 \mathrm{~m} \times 1 \mathrm{~m})$ located at the center of each grid cell using the method of Braun-Blanquet (1964). Names of plant species followed Hess and others (1984).

\section{Soil-Phosphorus Pool}

Five mineral soil cores $(1.5-\mathrm{cm}$ diameter) were taken to a depth of $20 \mathrm{~cm}$ at the edges and the center of each grid-cell subplot $(1 \mathrm{~m} \times 1 \mathrm{~m})$ immediately after completing the floristic survey in the summer of 1998. The shallow soils prevented deeper soil sampling. The soil cores from each subplot were combined, dried to constant weight at $60^{\circ} \mathrm{C}$, passed through a $2-\mathrm{mm}$ sieve, and analyzed for organic $\mathrm{P}$ concentration (soil-P) with the Tecator Flow Injection Analyser System 5012 Foss-Tecator, Höganäs, Sweden.

We estimated soil bulk density in 13 randomly selected grid cells by taking a $10 \mathrm{~cm} \times 10 \mathrm{~cm}$ sample to a depth of $20 \mathrm{~cm}$. Soil volume was estimated using the polyurethane foam technique (PageDumroese and others 1999). All bulk density samples were oven-dried at $105^{\circ} \mathrm{C}$, weighed, and passed through a $2-\mathrm{mm}$ sieve. Roots and rocks larger than $2 \mathrm{~mm}$ were separated and weighed. We estimated the soil-P pool in each grid cell by multiplying soil-P concentration with the mean fine fraction (less than $2 \mathrm{~mm}$ ) bulk density.

\section{Phosphorous Input by Feces}

The number of fecal pellet groups was counted in each grid cell $(20 \mathrm{~m} \times 20 \mathrm{~m})$ in July 1997. Additionally, we cleared all old feces from 46 systematically selected grid cells (every sixth grid cell) in early May 1998. New pellets were then collected from these cells monthly from late May until the end of September and dried to constant weight at $60^{\circ} \mathrm{C}$. We compared the 1998 input of dung in the 46 grid cells with the corresponding numbers of fecal pellet groups counted in July 1997. Yearly input of dung into each of the 268 grid cells was estimated by using the resulting linear regression equation:

$$
y=274.9 x+142.06
$$

where $y$ is dung dry weight $(\mathrm{g})$, and $x$ is number of fecal pellet groups counted in July 1997; $(n=46$, $\left.R^{2}=0.62, P<0.001\right)$.

We determined the average feces $\mathrm{P}$ concentration on 28 randomly selected feces samples. Samples were fine-ground and analyzed with the Tecator Flow Injection Analyser System 5012 for organic P.

\section{Phosphorus Removal by Grazing}

Based on the vegetation survey conducted in 1998, we stratified Alp Stabelchod into short- and tallgrass grid cells. We found 22 pairs of short- and tallgrass grid cells on a soil-P concentration gradient from 144 to $275 \mathrm{mg} \mathrm{P} \mathrm{kg}^{-1}$ soil, which met the following criteria: (a) the difference in soil-P concentration between cell pairs did not exceed $3 \mathrm{mg} P$ $\mathrm{kg}^{-1}$, and (b) the difference in short-grass proportion exceeded $50 \%$. Five additional grid cells with concentrations between 93 and $135 \mathrm{mg} \mathrm{P} \mathrm{kg}^{-1}$ were selected in the tall-grass vegetation only, because the short-grass community did not contain grid cells with concentrations lower than $144 \mathrm{mg} P$ $\mathrm{kg}^{-1}$.

Before red deer returned from their winter ranges located outside the park (immediately after snowmelt), we installed two grazing-proof wire baskets measuring $28 \times 48 \times 20 \mathrm{~cm}$ with a mesh size of $1.5 \mathrm{~cm}$ in the center of each selected grid cell (44 baskets in short-grass and 54 baskets in tall-grass) in early June 2001. As control plots, two similarsized areas were additionally established in each grid cell on unprotected vegetation. In mid-September, plants were clipped to a height of $2 \mathrm{~cm}$ aboveground on all plots and oven-dried to constant weight at $60^{\circ} \mathrm{C}$. The differences in biomass between the protected plots and unprotected controls corresponded to the amount of dry biomass (in g) consumed by red deer annually. To avoid 
underestimation of both plant production and biomass consumption (see, for example, McNaughton and others 1996), we used dry weights from baskets with a single clipping in September for our calculations because the productivity of monthly clipped vegetation was lower (936 versus $945 \mathrm{~kg} \mathrm{ha}^{-1}$ ).

The $\mathrm{P}$ concentration in leaf tissue (Leaf-P) of grazed vegetation was determined by establishing additional baskets in each of the 49 grid cells in early June. Plants were clipped several times to a height of $2 \mathrm{~cm}$ above ground until mid-September, mimicking the grazing behavior of red deer. Plant biomass was collected separately for each plot in a paper bag and oven-dried to constant weight at $60^{\circ} \mathrm{C}$. Samples were dry-ashed in a muffle furnace at $450^{\circ} \mathrm{C}$ for $6 \mathrm{~h}$, leached with $2 \mathrm{~N} \mathrm{HNO}_{3}$, and filtered. Analyses were conducted via inductively coupled plasma (ICP) for total P within the plant material (Weetman and Wells 1990). Because leaf$\mathrm{P}$ was significantly related to soil-P in short-grass but not in tall-grass vegetation (see Results), we used the following equation to estimate leaf-P and to calculate P removal as a function of soil-P for the short grass:

$$
y=0.0018 x+0.5943
$$

where $y$ is leaf $\mathrm{P}\left(\mathrm{g} \mathrm{kg}^{-1}\right)$, and $x$ is soil- $\mathrm{P}\left(\mathrm{g} \mathrm{kg}^{-1}\right)$ $\left(n=22, R^{2}=0.32, P=0.006\right)$.

We then multiplied the proportion of short-grass in each grid cell with the mean $P$ removal in the biomass of the short-grass stratum and added the proportion of tall-grass multiplied by the mean $P$ removal of the tall-grass stratum to determine $P$ removal per grid cell and year. Annual net $\mathrm{P}$ loss ( $\mathrm{P}$ removal minus $\mathrm{P}$ input) was also calculated for each grid cell.

\section{Data Analysis}

Before analysis, all data on dry biomass and shortgrass cover $(\%)$ were transformed using natural log and arcsin square root transformation, respectively, because they did not fulfill the normality and homogeneity criteria (Sokal and Rohlf 1995). Data on leaf tissue nutrient concentrations were not transformed, because they already met these criteria. We used linear regression analyses to test the relationships between the independent variable soil-P pool and the dependent variables short-grass proportion, dry biomass consumed, leaf-P, P removal, $\mathrm{P}$ input and net $\mathrm{P}$ loss (removal - input). The effect of the soil-P pool on the dependent variables dry biomass consumed, leaf $\mathrm{P}$, and $\mathrm{P}$ removal was tested separately for both strata on the scale of individual baskets using one-way analysis of variance (ANOVA). One-way ANOVAs were also used to test whether short-grass proportion, dry biomass consumed, $\mathrm{P}$ removal, $\mathrm{P}$ input, and net $\mathrm{P}$ loss (removal - input) per grid cell (grassland scale) depended on the soil-P pool. We used twoway ANOVA to compare (a) biomass consumption in short-grass versus tall-grass vegetation with short and tall-grass as fixed factors and (b) P removal with P input per grid cell over both the soil-P pool gradient and the short-grass cover gradient with $\mathrm{P}$ removal and $\mathrm{P}$ input as fixed factors. We calculated mean $\mathrm{P}$ removal/input for grid cells with the same short-grass cover before analysis ( $n$ reduced from 268 to 40 ). We compared mean annual net $\mathrm{P}$ loss with the successional development of the vegetation to estimate whether net $P$ loss is important in driving succession. We derived the succession stage of grid cells by comparing the vegetation composition of each grid cell with the vegetation composition of the long-term data from 59 permanent plots, as described in detail by Wildi and Schütz (2000). We described the relationship between soil-P pool and vegetation succession using a linear regression model.

\section{RESUlts}

\section{Spatial Patterns on Alp Stabelchod}

The organic $\mathrm{P}$ concentration in the mineral soil (soil-P) ranged from 0.072 to $0.322 \mathrm{~g} \mathrm{P} \mathrm{kg}^{-1}$ in the 268 grid cells. Based on an average bulk density of $0.547 \mathrm{~g} \mathrm{~cm}^{-3}$ (short-grass $=0.599 \mathrm{~g} \mathrm{~cm}^{-3}$, tallgrass $\left.=0.515 \mathrm{~g} \mathrm{~cm}^{-3}, P=0.33\right)$, we estimated that soil-P pools ranged from 79 to $352 \mathrm{~kg} \mathrm{P}^{-1}$ (Figure 1A). Soil-P pools generally were highest in the eastern part of Alp Stabelchod north and south of the cottage, whereas lowest values were found in the southwestern part adjacent to the forest (Figure 1A). The proportion of short-grass vegetation was highly correlated to soil-P pools $(n=40$, $R^{2}=0.63, P<0.001$ ), (Figure 1C), with the highest short-grass cover (more than $95 \%$ per grid cell) in the eastern part (average soil-P pools of $251 \mathrm{~kg} P$ $\mathrm{ha}^{-1}$ ) and no short-grass cover in the western part of Alp Stabelchod (average soil-P pools of $154 \mathrm{~kg} \mathrm{P}$ $\mathrm{ha}^{-1}$ ), (Figure 1B).

\section{Phosphorus Removal, Phosphorus Input, and Phosphorus Balance}

Our clipping experiment (individual baskets) showed that biomass consumption by red deer was significantly higher in the short-grass area compared to the tall-grass vegetation $(n=22$, 


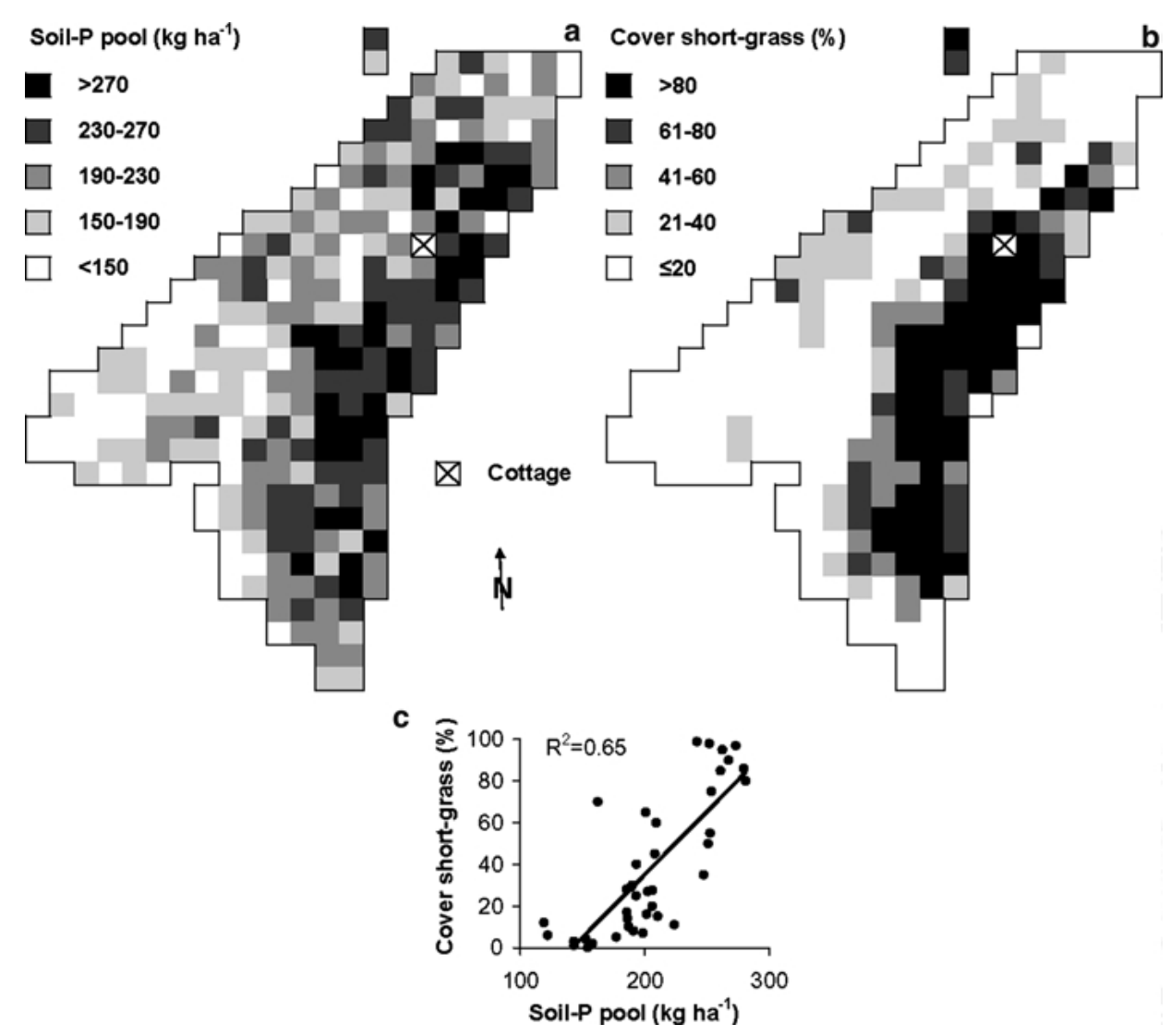

Figure 1. Spatial patterns of a mineral soil-phosphorus (P) pool (top $20 \mathrm{~cm}$ ), b cover of heavily grazed short-grass vegetation (\%), and c relationship between soil-P pool and cover of short-grass vegetation on the subalpine grassland of Alp Stabelchod in the Swiss National Park.

$P=0.03)$. In short-grass vegetation, red deer consumed $945 \mathrm{~kg}$ dry biomass per hectare per year, or $85 \%$ of the annually produced $1,110 \mathrm{~kg} \mathrm{ha}^{-1}$ total biomass. In contrast, only $438 \mathrm{~kg} \mathrm{ha}^{-1} \mathrm{y}^{-1}$, or $17 \%$ of the annually produced $2,537 \mathrm{~kg} \mathrm{ha}^{-1}$ total biomass, was consumed in tall-grass vegetation. Consumption did not depend on soil-P pool in either vegetation type (short-grass: $n=44, R^{2}=0.06$, $P=0.27$, tall-grass: $\left.n=54, R^{2}=0.04, P=0.31\right)$, (Figure 2A), but leaf-P concentration increased with increasing soil-P pool in short-grass vegetation $\left(n=22, R^{2}=0.32, P=0.006\right)$, (Figure $\left.2 \mathrm{~B}\right)$, with values ranging from $0.88 \mathrm{~g} \mathrm{~kg}^{-1}$ (soil-P pool $=158$ $\mathrm{kg} \mathrm{ha}{ }^{-1}$ ) to $1.13 \mathrm{~g} \mathrm{~kg}^{-1}$ dry biomass (soil-P pool $=299 \mathrm{~kg} \mathrm{ha}^{-1}$ ). In contrast, we did not detect a relationship between leaf-P and soil-P pools in tall-grass vegetation (mean $\mathrm{P}$ concentration $=1.04$ $\mathrm{g} \mathrm{kg}^{-1}$ dry biomass, $n=27, R^{2}=0.12, P=0.08$ ) (Figure 2B). Despite the strong correlation between short-grass leaf-P and soil-P pool, P removal (basket scale) was not correlated with soil-P pool in either vegetation type (mean $P$ removal short-grass: 0.95 kg P ha $\mathrm{y}^{-1}, n=44, R^{2}=0.07, P=0.08$; tallgrass: $0.49 \mathrm{~kg} \mathrm{P} \mathrm{ha}^{-1} \mathrm{y}^{-1}, n=54, R^{2}=0.06$, $P=0.07$ ) (Figure 2C). At the grassland scale, high $P$ removal rates were detected for the eastern part of the Alp (Figure 3A) due to a higher proportion of short-grass vegetation $\left(n=40, R^{2}=0.94, \quad P<\right.$ $0.001)$, (Figure 3C). These grid cells had proportionally higher biomass consumption, which in turn was correlated to the soil-P pool $\left(n=268, R^{2}\right.$ $=0.47, P<0.001$ ) (Figure. 3D). Overall, $\mathrm{P}$ removal rates ranged from 0.08 to $0.95 \mathrm{~kg} \mathrm{P} \mathrm{ha}^{-1} \mathrm{y}^{-1}$ in the grassland.

The quantity of dung was highly variable among the grid cells (0.14-16 kg dry weight). Based on an average fecal $\mathrm{P}$ concentration of $3.92 \mathrm{~g} \mathrm{P} \mathrm{kg}^{-1}$, we calculated $\mathrm{P}$ input rates ranging from 0.014 to $1.576 \mathrm{~kg} \mathrm{P} \mathrm{ha}^{-1} \mathrm{y}^{-1}$ (Figure 3B). The spatial pattern of feces-P additions was similar to that of $\mathrm{P}$ removal through grazing (Figure 3B) and was positively related to short-grass cover $\left(n=40, R^{2}=0.57, P<\right.$ $0.001)$, (Figure 3C) and soil-P pool $(n=268$, $\left.R^{2}=0.0 .25, P<0.001\right)$, (Figure $\left.3 \mathrm{D}\right)$.

Rates of $\mathrm{P}$ removal and $\mathrm{P}$ input increased with increasing short-grass cover and soil-P pool (Figure 3C, D). Removal rates ranged from $0.305 \mathrm{~kg} \mathrm{P} \mathrm{ha}^{-1} \mathrm{y}^{-1}$ (soil-P pool $=79 \mathrm{~kg} \mathrm{ha}^{-1}$ ) to $0.988 \mathrm{~kg} \mathrm{P} \mathrm{ha}{ }^{-1} \mathrm{y}^{-1}$ (soil-P pool $=352 \mathrm{~kg} \mathrm{ha}^{-1}$ ), whereas input rates were between 0.207 and 0.916 $\mathrm{kg} \mathrm{P} \mathrm{ha} \mathrm{y}^{-1} \mathrm{y}^{-1}$. We found a highly significant positive correlation between $\mathrm{P}$ removal through grazing 

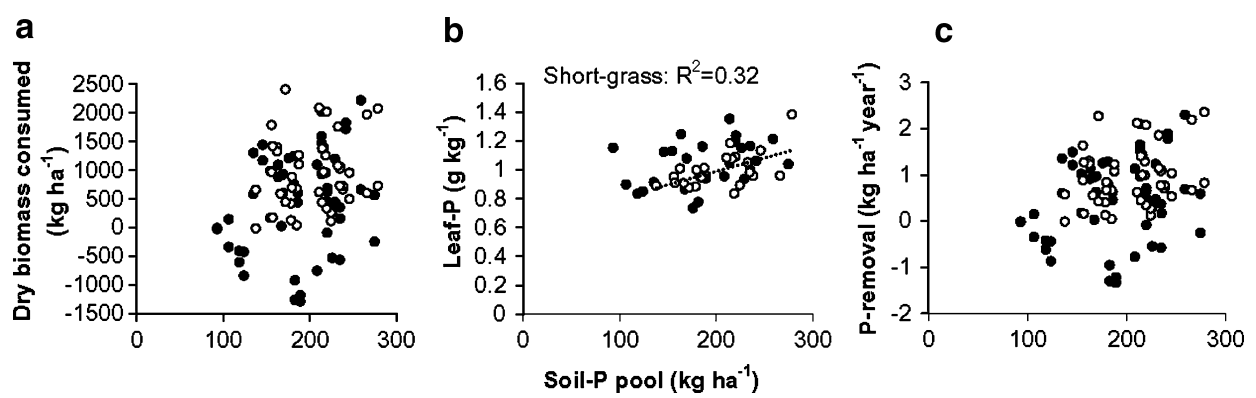

Figure 2. Relationship between soil-phosphorus (P) pool and dry biomass consumed by red deer a soil-P pool and P concentration of leaf tissue $\mathbf{b}$ and soil-P pool and P removal by red deer grazing $\mathbf{c}$ in the short-grass $(\mathrm{O}$-dashed line) and tall-grass (-) vegetation on Alp Stabelchod.
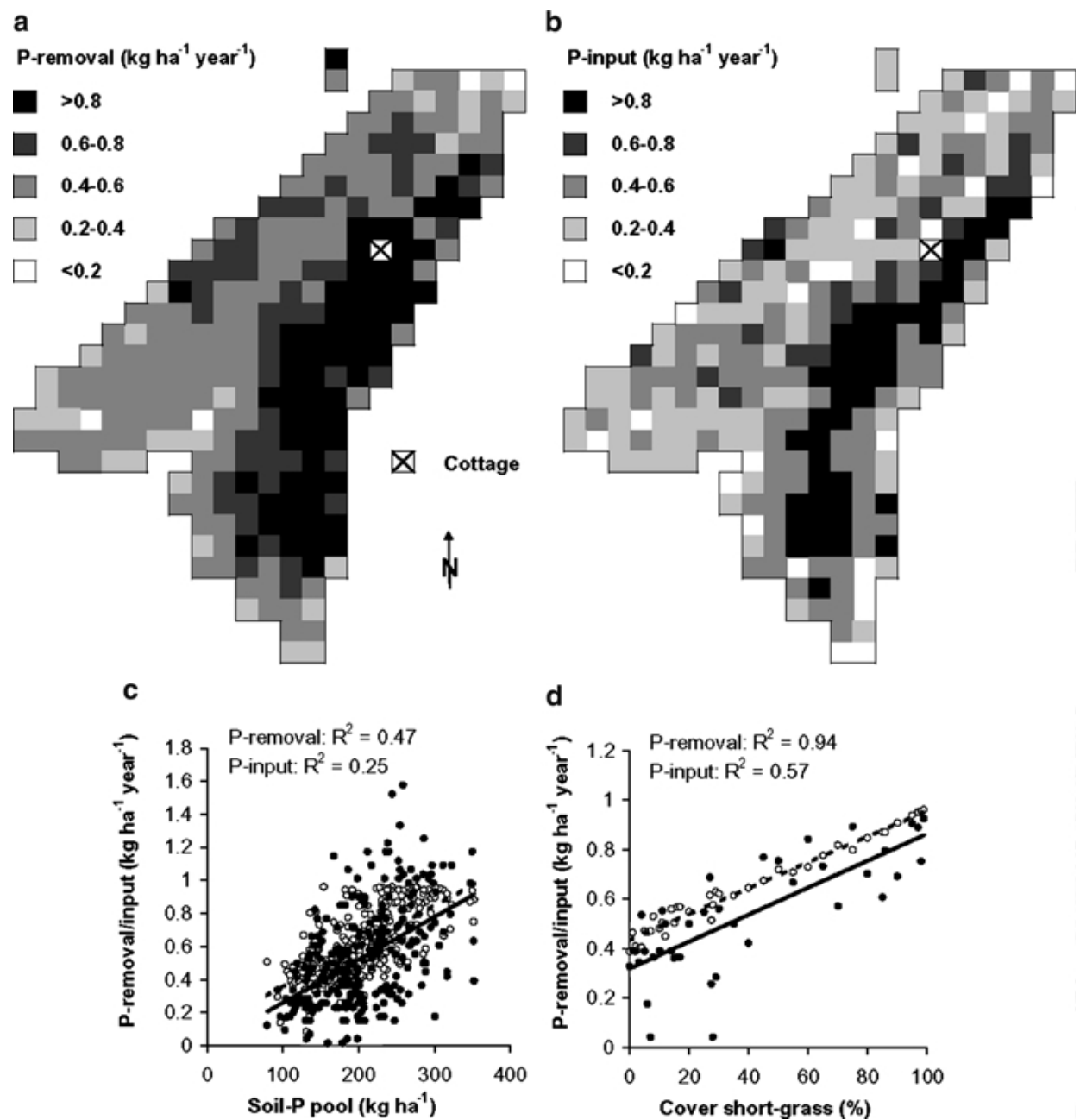

Figure 3. Spatial patterns of A phosphorus (P) removal by red deer grazing offtake, and $\mathbf{B}$ P input by red deer dung deposition on the subalpine grassland of Alp Stabelchod C Relationship between $\mathrm{P}$ removal/P input and soil-P pool. D Relation between $\mathrm{P}$ removal/P input and short-grass cover. $\mathrm{P}$ removal, $\mathrm{O}$-dashed line; $\mathrm{P}$ input, @-solid line.

d

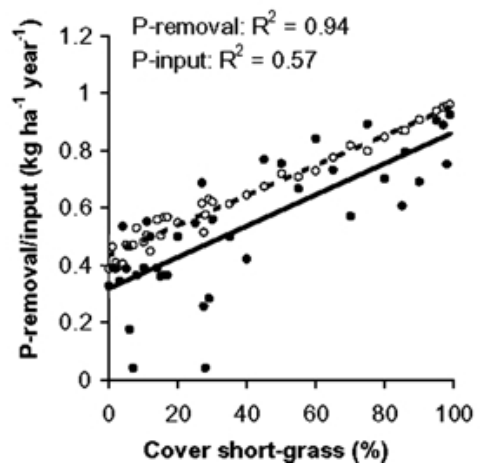

and $\mathrm{P}$ input by feces $\left(n=268, R^{2}=0.39, P<\right.$ 0.001 ); for example, high P removal due to grazing in the eastern part of Alp Stabelchod was balanced by high fecal $\mathrm{P}$ inputs (Figure 3A, B).

Overall, $\mathrm{P}$ removal rates were significantly higher than $\mathrm{P}$-input rates $(P<0.001)$, averaging a net $\mathrm{P}$ loss of $0.083 \mathrm{~kg} \mathrm{P} \mathrm{ha} \mathrm{y}^{-1} \mathrm{y}^{-1}$ independent of soil-P pool $\left(n=268, R^{2}=0.0007, P=0.65\right)$ and shortgrass cover $\left(n=40, R^{2}=0.0002, P=0.92\right)$ (Figure $4 \mathrm{~A}, \mathrm{~B})$. On the single grid cell scale, we found that the soil-P balance varied between losses of $0.74 \mathrm{~kg} \mathrm{Pha}^{-1} \mathrm{y}^{-1}$ and gains of $0.66 \mathrm{~kg} \mathrm{P} \mathrm{ha}^{-1} \mathrm{y}^{-1}$. Grid cells crossed by hiking trails had higher $\mathrm{P}$ losses (216 $\left.\mathrm{g} \mathrm{P} \mathrm{ha}^{-1} \mathrm{y}^{-1}\right)$ due to smaller $\mathrm{P}$ additions 

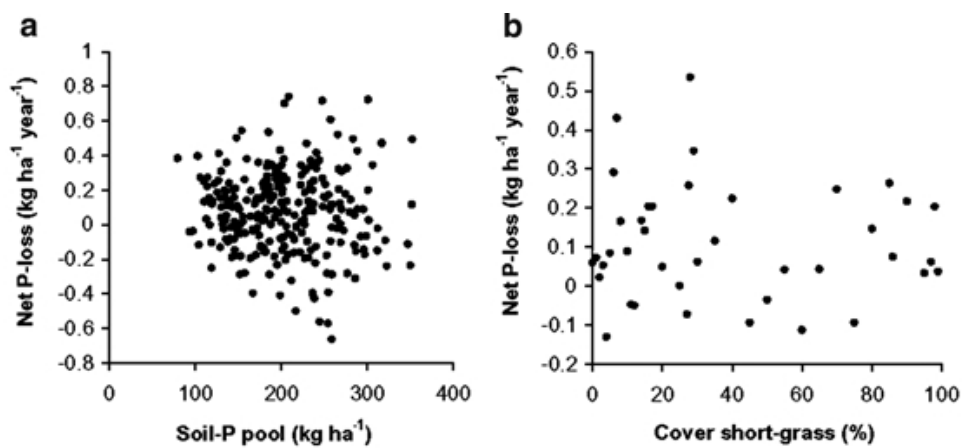

Figure 4. Relationship between a net phosphorus (P) loss and soil-P pool, b net $\mathrm{P}$ loss and cover of shortgrass vegetation. Spatial patterns of $\mathbf{c}$ net $\mathrm{P}$ loss (removal $>$ input) and $\mathbf{d}$ net $\mathrm{P}$ gain (input $>$ removal) on the subalpine grassland of Alp Stabelchod.

C

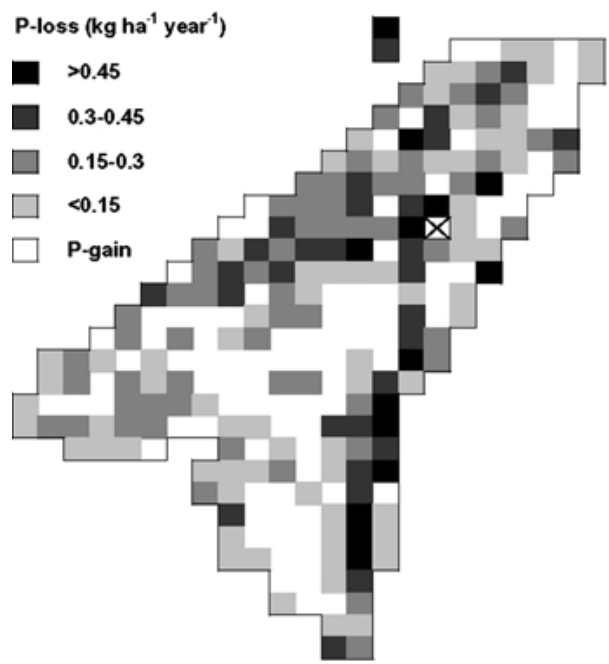

d

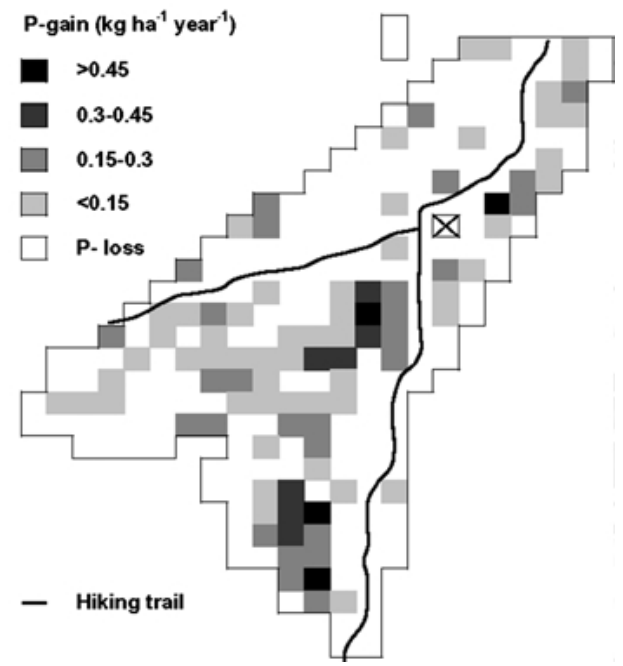

from feces (Figure 4C, D), compared with the average losses of $50 \mathrm{~g} \mathrm{P} \mathrm{ha}^{-1} \mathrm{y}^{-1}$ calculated for undisturbed grid cells.

\section{Net Phosphorus-Loss and Succession}

The vegetation within the 268 grid cells on Alp Stabelchod represents succession stages from shortgrass vegetation dominated by Festuca rubra L. (early stages) to tall-grass vegetation with a predominance of Carex sempervirens Vill. (late stages). We found a negative correlation between succession stage and soil-P pool $\left(n=268, R^{2}=0.33, P<0.001\right)$. Because we observed a constant $\mathrm{P}$ loss independent of soil-P pool, we described the correlation in a linear model (Figure 5). The model predicts a decrease in soil-P pool from $250 \mathrm{~kg} \mathrm{P} \mathrm{ha}^{-1}$ in the earliest succession stages to $112 \mathrm{~kg} \mathrm{P} \mathrm{ha}^{-1}$ in the latest stages. If we assume (a) an average net $\mathrm{P}$ loss rate of $0.083 \mathrm{~kg} \mathrm{P}$ $\mathrm{ha}^{-1} \mathrm{y}^{-1}$ (= increase from $0.03 \%$ yearly soil-P pool loss in earliest stage to $0.07 \%$ loss in latest stage) and (b) that there are no other $\mathrm{P}$ sinks or $\mathrm{P}$ sources existing, it would take 1,660 years for the soil-P pool found in the most P-rich parts of Alp Stabelchod today to be depleted to the current levels observed in the P-poor parts near the forest edge.

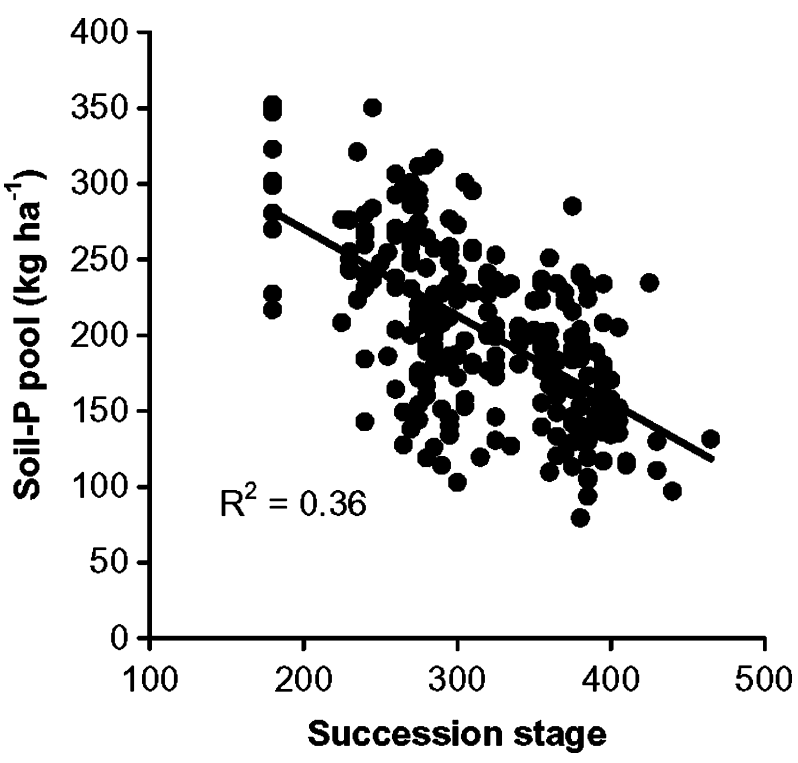

Figure 5. Pattern of the soil-phosphorus (P) pool in relation to the succession stage of the vegetation in 268 grid cells on Alp Stabelchod. A linear model was fitted. Low number of succession stage = early succession stage; high number $=$ late succession stage. 


\section{Discussion}

\section{Biomass Consumption}

The subalpine grassland ecosystem of Alp Stabelchod is characterized by distinct spatial patterns. Soils in the eastern part of the grassland around former stables are P-rich and gradually become impoverished toward the western part and the forest edges. Vegetation and soil patterns were found to be highly correlated: increasing proportion of heavily grazed short-grass vegetation and decreasing proportion of rarely grazed tall-grass vegetation were positively related to increasing soil-P. Consequently, the total amount of biomass consumed by red deer was higher in P-rich than Ppoor areas. Also, other studies have found that nutrient-rich grasslands dominated by Festuca are the preferred grazing sites for red deer hinds (Charles and others 1977; Clutton-Brock and others 1987; Gordon 1989). Hinds select plant material that is low in fiber and high in nutrients (Moss and others 1981; Staines and others 1982; Welch and Scott 1995) to satisfy their high energy requirements during pregnancy and lactation (Georgii 1980). Because (a) red deer hinds prefer to graze on nutrient-rich sites, and (b) continuous grazing is known to maintain a high nutrient concentration in plants throughout the growing season (Cargill and Jefferies 1984; Iason and others 1986; Gauthier and others 1995; Fox and others 1998), female deer tend to feed on areas that have already been grazed earlier in the season (Clark and others 1995; Märki and others 2000). Our results agree with these findings.

\section{Phosphorus Balance}

We found that P-removal rates were higher from Prich than from P-poor areas, because biomass consumption by red deer increased with increasing soil-P pool. However, P-input rates due to the deposit of feces were also higher where biomass consumption was higher. Neff (1968) and Charles and others (1977) reported that the feeding patterns of large herbivores, such as red deer, may be fairly well represented by feces patterns, thus supporting our results. In contrast to our hypothesis, net P loss on Alp Stabelchod was not restricted to P-enriched areas, which are preferably grazed by red deer, but was independent of grazing intensity, soil-P pool, and P concentration in leaf tissue.

Because we found higher $\mathrm{P}$ removal than $\mathrm{P}$ input rates on Alp Stabelchod (average annual net $\mathrm{P}$ loss, $0.083 \mathrm{~kg} \mathrm{P} \mathrm{ha}^{-1}$ ), it seems that the soil-P enrichment caused by cattle is slowly being reversed by red deer. Under today's grazing regime, we estimated that it would take 1,660 years for the soil-P pool in the most P-rich parts of Alp Stabelchod to be depleted to the levels observed in the P-poor parts near the forest edge. Overall, our yearly net $\mathrm{P}$ losses of $0.03-0.07 \%$ of the soil$\mathrm{P}$ pool were comparable to results reported for vegetation communities grazed by elk in the Rocky Mountain National Park (Schoenecker and others 2002), where substantial reductions of nitrogen pools were observed in willow and aspen communities, while pine forests became enriched. For meadow or grassland/shrub communities, however, almost no changes in nitrogen pools were found-that is, losses were less than $2 \%$ over 50 years.

Although the estimated 1,660 years for soil-P depletion seems to represent a very slow process it is likely that the processes discussed are even slower, because we might have overestimated the annual net $\mathrm{P}$ loss in grid cells crossed by hiking trails. Park rangers often remove pellets during trail maintenance, which would result in a higher annual net $\mathrm{P}$ loss compared to undisturbed cells. Calculations based on the annual net $\mathrm{P}$ loss of undisturbed grid cells only indicated that it would take 2,770 years to remove the accumulated $P$ from cattle grazing. Using this scenario, the net $\mathrm{P}$ loss would vary between $1 \%$ and $2.2 \%$ of the soil-P pool per 50 years.

We are aware that these are estimates and that the calculated rate of P-depletion could have been influence by under- or overestimations of the variables measured in our study. For example, the method used for estimating aboveground productivity and biomass consumption in grazing ecosystems can produce considerable biases (for a detailed discussion, see McNaughton and others 1996), which in our case could lead to an underor overestimation of net P losses. Additionally, our study encompassed several years of measurements, during which grazing patterns or the population size of red deer could have changed. However, based on annual records, we are confident that red deer population size stayed quite constant between 1997 and 2001 (Haller 2002). We therefore are convinced that our approach is accurate enough to gain a good understanding of functions and processes in this grassland ecosystem. However, a future experimental approach, in which grazing would be separated from Ptranslocation effects by establishing a combined grazing pressure and fecal pellet redistribution gradient, would be helpful to test our interpretations. 


\section{Effects of Net Phosphorus Loss on Succession}

Interactions between soil fertility and vegetation development can be complex. An accumulation of $\mathrm{P}$ and an increase in $\mathrm{P}$ mineralization are generally found during primary succession (Frizano and others 2002), although these trends are much more variable during secondary succession. Increases (Johnson and others 2001) as well as decreases in inorganic P (Abadin and others 2002) have been reported.

Our estimated average $\mathrm{P}$ loss $\left(0.83 \mathrm{~g} \mathrm{P} \mathrm{ha}^{-1} \mathrm{y}^{-1}\right)$ is so small that it is not likely that $\mathrm{P}$ depletion has been the driving force behind the floristic changes observed in the heavily grazed parts of Alp Stabelchod during the past 60 years (Schütz and others 2003). Within a few decades, tall-herb/meadow communities lost dominance in the most P-rich parts of the grassland and were replaced by a Festuca rubra L. dominated short-grass pasture. Parallel to these changes in community structure, we found marked increases in the number of plant species in the P-rich parts, whereas no change in species richness was found in the P-poor, rarely grazed tall-grass communities (Schütz and others 2003). Additionally, plants with physiological and morphological adaptations to grazing became more abundant since abandonment of the grassland: (a) small-growing species (for example Carex capillaris L., C. verna Chaix, Prunella vulgaris L., Trichophorum pumilum (Vahl.) Schinz et Thellung, Viola rupestris F.W. Schmidt), (b) species with morphological (Carlina acaulis L., Cirsium acaule (L.) Scop.) or chemical protection (Ranunculus acer L.), and (c) annuals such as Euphrasia montana Jordan and Gentiana nivalis L. (Schütz and others 2003). Based on these indications, we therefore suggest that disturbance by grazing rather than $\mathrm{P}$ translocation by red deer was the major driver behind the observed vegetation development. Grazing by red deer reduced the dominance of the competitive tall-growing species found in tall-herb/meadow communities (Grime 1979; Palo and Robbins 1991; Olofsson 2001; Wohlgemuth and others 2002), enabling a larger array of life strategies to be competitive and species richness to increase.

We therefore conclude that vegetation changes from tall-herb/meadow communities to short-grass pastures were caused by grazing disturbance rather than by P translocation. Phosphorus translocation, however, will likely have a long-term effect on vegetation development because depletion will eventually lead to a reduction in grazing pressure. The reduced grazing pressure will in turn enable the establishment of tall-grass vegetation and finally forest stands. Our results indicate that cyclic succession within the grassland is unlikely to occur, because the P-rich short-grass vegetation is not depleted in favor of P-poor tall-grass vegetation. Thus, shifts in the grazing preference of red deer from short- to tall-grass vegetation are not likely.

\section{ACKNOWLEDGEMENTS}

This study was supported by the Swiss National Science Foundation (grants 3100-045944.95 and 3100-064158.00). We thank the Swiss National Park for permission to carry out this study in the park and for lodging in the laboratory at Il Fuorn. We are grateful to R. Trachsler, A. Hegi, J. Hensiek, and J. Tirocke for their assistance with laboratory work. We also thank Silvia Dingwall for checking the language. Two anonymous reviewers provided helpful comments that improved this Paper.

\section{REFERENCES}

Abadin J, Gonzalez-Prieto SJ, Sarmiento L, Villar MC, Carballas T. 2002. Successional dynamics of soil characteristics in a long fallow agricultural system of the high tropical Andes. Soil Biol Biochem 34:1739-48.

Achermann G, Schütz M, Krüsi BO, Wildi O. 2000. Tall-herb communities in the Swiss National Park: long-term development of the vegetation. Nationalpark-Forschung Schweiz 89:67-88.

Bokdam J. 2001. Effects of browsing and grazing on cyclic succession in nutrient-limited ecosystems. J Veget Sci 12:875-86.

Braun-Blanquet J. 1964. Vegetation sociology: the study of plant communities. London: Hafner, 439 p.

Braun-Blanquet J, Brunies S, Campell E, Frey E, Jenny H, Meylan C, Pallmann H. 1931. Vegetationsentwicklung im Schweizerischen Nationalpark. Ergebnisse der Untersuchung von Dauerbeobachtungsflächen. Jahresbericht Naturforschenden Gesellschaft Graubündens 69:3-82.

Cargill SM, Jefferies RL. 1984. The effects of grazing by lesser snow geese on the vegetation of a sub-arctic salt marsh. J Appl Ecol 21:669-86.

Charles WN, McCowan D, East K. 1977. Selection of upland swards by red deer (Cervus elaphus L.) on Rhum. J Appl Ecol 14:55-64.

Clark JL, Welch D, Gordon IL. 1995. The influence of vegetation pattern on the grazing of heather moorland by red deer and sheep. I. The location of animals on grass/heather mosaics. J Appl Ecol 32:166-76.

Clutton-Brock TH, Iason GR, Guiness FE. 1987. Sexual segregation and density-related changes in habitat use in male and female red deer (Cervus elaphus). J Zool 211:275-89.

Collins SL, Knapp AK, Briggs JM, Blair JM, Steinauer EM. 1998. Modulation of diversity by grazing and mowing in native tallgrass prairie. Science 280:745-7.

Detling JK. 1988. Grasslands and savannas: regulation of energy flow and nutrient cycling by herbivores. Ecol Stud 67:131-48.

Dietl W. 1994. Alpwirtschaft. Zollikofen: Landwirtschaftliche Lehrmittelzentrale (LMZ), 150 p. 
Edwards PJ, Hollis S. 1982. The distribution of excreta on New Forest grassland used by cattle, ponies and deer. J Appl Ecol 19:953-64.

Fox AD, Kristiansen JN, Stroud DA, Boyd H. 1998. The effect of simulated spring goose grazing on the growth rate and protein content of Phleum pratense leaves. Oecologia 116:154-9.

Frank DA, Evans RD. 1997. Effects of native grazers on grassland $\mathrm{N}$ cycling in Yellowstone National Park. Ecology 78:2238-48.

Frizano J, Johnson AH, Vann DR, Scatena FN. 2002. Soil phophorus fractionation during forest development on landslide scars in the Luquillo Mountains, Puerto Rico. Biotropica 34:17-26.

Gauthier G, Hughes RJ, Reed A, Beaulieu J, Rochfort L. 1995. Effects of grazing by greater snow geese on the production of graminoids at an arctic site (Bylot Island, NWT, Canada). J Ecol 83:653-64.

Georgii B. 1980. Home range patterns of female red deer (Cervus elaphus L.) in the Alps. Oecologia 47:278-85.

Gordon IJ. 1989. Vegetation community selection by ungulates on the Isle of Rhum. II. Vegetation community selection. J Appl Ecol 26:53-64.

Gough L, Grace JB. 1998. Herbivore effects on plant species density at varying productivity levels. Ecology 79:1586-94.

Grämiger H, Krüsi BO. 2000. Balthasar Stüssi, 17 July 1908-24 October 1992. Nat park-Forsch Schweiz 89:27-38.

Grime JP. 1979. Plant strategies and vegetation processes. Chichester: Wiley, 222 p.

Haller H. 2002. Der Rothirsch im Nationalpark und dessen Umgebung. Liestal: Lüdin, $144 \mathrm{p}$.

Hess HE, Landolt E, Hirzel R. 1984. Bestimmungsschlüssel zur Flora der Schweiz. Basel: Birkhäuser, 657 p.

Hilal MH, Anter F, El-Damaty AH. 1973. A chemical and biological approach towards the definition of calcareous soils. I. Movement and retention of $\mathrm{P}^{32}$ in soils as affected by percentage and particle size of calcium carbonate fraction. Plant Soil 39:469-78.

Iason GR, Duck CD, Clutton-Brock TH. 1986. Grazing and reproductive success of red deer: the effect of local enrichment by gull colonies. J Appl Ecol 55:507-15.

Johnson CM, Vieira ICG, Zarin DJ, Frizano J, Johnson AH. 2001. Carbon and nutrient storage in primary and secondary forests in eastern Amazonia. Forest Ecol Manage 147:245-52.

Knapp AK, Blair JM, Collins SL, Hartnett DC, Johnson LC, Towne EG. 1999. The keystone role of bison in North American tallgrass prairie. BioScience 49:39-50.

McNaughton SJ, Milchunas DG, Frank DA. 1996. How can net primary productivity be measured in grazing ecosystems? Ecology 77:974-7.

McNaughton SJ, Banyikawa FF, McNaughton MM. 1997. Promotion of the cycling of diet-enhancing nutrients by african grazers. Science 278:1798-800.

Märki K, Nievergelt B, Gigon A, Schütz M. 2000. Impact of selective foraging by red deer on the long-term vegetation development in the Swiss National Park. Nat park-Forsch Schweiz 89:189-206.

Moss R, Welch D, Rothery P. 1981. Effects of grazing by mountain hares and red deer on the production and chemical composition of heather. J Appl Ecol 18:487-96.

Neff DJ. 1968. The pelet-group count technique for big game trend, census and distribution. J Wild Manage 32:597-614.
Olofsson J. 2001. Influence of herbivory and abiotic factors on the distribution of tall forbs along a productivity gradient: a transplantation experiment. Oikos 94:351-7.

Page-Dumroese DS, Jurgensen MF, Brown RE, Mroz GD. 1999. Comparison of methods for determining bulk densities of rocky soils. Soil Sci Soci Am J 63:379-83.

Palo RT, Robbins CT. 1991. Plant defenses against mammalian herbivores. Boston: CRC, 192 p.

Putman RJ. 1986. Grazing in temperate ecosystems: large herbivores and the ecology of the New Forest. London: Croom Helm, $210 \mathrm{p}$.

Risch AC, Nagel LM, Schütz M, Krüsi BO, Kienast F, Bugmann H. 2003. Structure and long-term development of subalpine Pinus montana Miller and Pinus cembra L. forests in the central European Alps. Forstw cbl 122:219-30.

Schoenecker KA, Singer FJ, Menezes RSC, Zeigenfuss LC, Binkley D. 2002. Sustainability of vegetation communities grazed by elk in Rocky Mountain National Park. In: Singer FJ, Zeigenfuss LC, Eds. Ecological evaluation of the abundance and effects of elk herbivory in Rocky Mountain National Park, 1994-1999. Open Report 02-208. Fort Collins (CO): US Geological Survey. p 187-204.

Schütz M, Risch AC, Leuzinger E, Krüsi BO, Achermann G. 2003. Impact of herbivory by red deer (Cervus elaphus L.) on patterns and processes in subalpine grasslands in the Swiss National Park. Forest Ecol Manage 181:177-87.

Sokal RR, Rohlf JF. 1995. Biometry. 3rd ed. New York: Freeman, $887 \mathrm{p}$.

Spatz G. 1980. Succession patterns on mountain pastures. Vegetatio 43:39-41.

Staines BW, Crisp JM, Parish T. 1982. Differences in the quality of food eaten by red deer (Cervus elaphus) stags and hinds in winter. J Appl Ecol 19:65-77.

Stüssi B. 1970. Naturbedingte Entwicklung subalpiner Weiderasen auf Alp La Schera im Schweizerischen Nationalpark während der Reservatsperiode 1939-1965. Ergebnisse der wissenschaftlichen Untersuchungen im Schweizerischen Nationalpark 61:1-385.

Virtanen R, Edwards GR, Crawley MJ. 2002. Red deer management on the Isle of Rum. J Appl Ecol 39:572-83.

Weetman GF, Wells CG. 1990. Plant analysis as an aid in fertilizing forests. In: Westman RL, Ed. Soil testing and plant analysis. Madison (WI): Soil Science Society of America. p 659-90.

Welch D, Scott D. 1995. Studies in the grazing of heather moorland in northeast Scotland. J Appl Ecol 32:596-611.

Wildi O, Schütz M. 2000. Reconstruction of a long-term recovery process from pasture to forest. Comm Unity Ecol 1:25-32.

Willot SJ, Miller AJ, Incoll LD, Compton SG. 2000. The contribution of rabbits (Oryctolagus cuniculus L.) to soil fertility in semi-arid Spain. Biol Fertil Soils 31:379-84.

Wohlgemuth T, Bürgi M, Scheidegger C, Schütz M. 2002. Dominance reduction of species through disturbance-a proposed management principle for central European forests. Forest Ecol Manage 166:1-15.

Wu Z, Sutter LD, Sojo R. 2000. Milk production, reproductive performance and faecel excretion of phosphorus by dairy cows fed three amounts of phosphorus. J Dairy Sci 83:1028-41. 